\title{
The Impact of Supply Chain Management Practices on Supply Chain Performance in Jordan: The Moderating Effect of Competitive Intensity
}

\author{
Ayman Bahjat Abdallah ${ }^{1}$, Bader Yousef Obeidat ${ }^{2} \&$ Noor Osama Aqqad ${ }^{2}$ \\ ${ }^{1}$ Faculty of Economics and Administrative Sciences, Applied Science University, Jordan \\ ${ }^{2}$ Department of Business Management, Faculty of Business, The University of Jordan, Jordan \\ Correspondence: Ayman Bahjat Abdallah, Department of Business Administration, Faculty of Economics and \\ Administrative Sciences, Applied Science University, Amman 11931, P.O.Box 166, Jordan. Tel: \\ 962-786-951282. E-mail: aymanabdallah@yahoo.com
}

Received: December 13, 2013

Accepted: December 30, 2013

Online Published: February 24, 2014

doi:10.5539/ibr.v7n3p13

URL: http://dx.doi.org/10.5539/ibr.v7n3p13

\begin{abstract}
The purpose of this study is to test the impact of supply chain management practices on supply chain performance in terms of supply chain efficiency and supply chain effectiveness. Additionally, we investigate the moderating effect of competitive intensity on the relationship between supply chain management practices and supply chain performance. Data for this research were collected from 104 manufacturing companies in Jordan. Hierarchical regressions were used to test the hypothesized relationships. The results indicate that three supply chain management practices, internal integration, information sharing, and postponement, but not supplier integration and customer integration, significantly and positively affect supply chain efficiency performance. Competitive intensity moderates the relationship between each of internal integration, supplier integration, and customer integration, and supply chain efficiency performance. The results also show that three supply chain management practices, internal integration, customer integration, and postponement, but not supplier integration and information sharing, significantly and positively affect supply chain effectiveness performance. Competitive intensity moderates the relationship between each of customer integration and information sharing, and supply chain effectiveness performance.
\end{abstract}

Keywords: supply chain management, supply chain performance, supply chain efficiency, supply chain effectiveness, competitive intensity

\section{Introduction}

Supply chain management (SCM) has become a hot research area during the last decade. Many research papers were published in an attempt to develop SCM practices and to investigate their impact on operational, organizational, and supply chain performance (e.g., Li et al., 2004; Flynn et al., 2010; Cook \& Heiser, 2011; Ibrahim \& Ogunyemi, 2012). However, the results of the existing research are characterized by mixed and contradicting results leading to confusion among researchers. Part of the contradicting results is attributed to the usage of different practices to measure SCM and supply chain performance. Another part of the mixed results could be attributed to overlooking some vital contextual factors that may potentially explain the variation of the results in the SCM literature. Additionally, SCM research is mainly focused on companies in developed countries. Companies in developing countries face a real challenge to improve their operational capabilities, including $\mathrm{SCM}$, in order to be able to compete and survive in today's competitive environment. Competition has dramatically increased during the last two decades. The current business environment is characterized by factors such as globalization, free trade agreements, and open markets. To shed more light on the relationship between SCM practices and SC performance, we include competitive intensity as a moderating variable to investigate its effect on this relationship.

The competitive situation in Jordan today is similar to many other countries. Up to the new millennium; the manufacturing sector in Jordan had been protected from foreign competitors by different entry barriers and regulations imposed by the government. Also, the manufacturers of Jordan enjoyed a favorable export market to Iraq until 2003. At the dawn of the new millennium, the government of Jordan started a new era of reforms to 
improve the economic situation and attract foreign investments to the country. Several new international agreements were signed, which completely changed the traditional protection for local industries including the manufacturing sector, such as free trade agreements with the United States, Canada, Turkey, and Singapore, membership of World Trade Organization (WTO), partnership agreement with the European Union, and membership of the Arabic free trade zone (www.mit.gov.jo).

\subsection{Purpose of the Paper}

To address the raised issues, we explored the impact of SCM practices on SC performance in manufacturing companies in Jordan. We conducted a thorough review of the published SCM literature to determine the most widely used SCM practices and SC performance dimensions. We then examined the impact of individual SCM practices on SC performance dimensions. Next, we sought to test the effect of competitive intensity on this relationship. Our study is expected to make a considerable contribution to the exiting literature as most companies today operate under high levels of competitive intensity.

\section{Literature Review}

\subsection{Supply Chain Management}

Several definitions of supply chain management were proposed by researchers in the literature. Stock and Boyer (2009) defined SCM as "The management of a network of relationships within a firm and between interdependent organizations and business units consisting of material suppliers, purchasing, production facilities, logistics, marketing, and related systems that facilitate the forward and reverse flow of materials, services, finances and information from the original producer to final customer with the benefits of adding value, maximizing profitability through efficiencies, and achieving customer satisfaction".

Researchers have pointed to several objectives and goals of SCM. Williams (2006) stated that long term objectives include improving efficiency and effectiveness of supply chain partners, improving market share and profits, and increasing customer satisfaction. Short term objectives of SC include increasing productivity, and reducing cycle time and inventories (Wisner \& Tan, 2000).

Several dimensions and practices of SCM were proposed in the literature. Cook and Heiser (2011) defined the following SCM practices: information sharing, long range relationships, advanced planning techniques, leveraging the internet, and supply and distribution network structures. They found a positive relationship between SCM practices and organizational performance with the moderating effect of supply chain role. Li et al. (2004) developed and validated five dimensions of SCM practices: supplier and customer relationships, level and quality of information sharing, and postponement. They found a positive effect of SC practices on competitive advantage and organizational performance. Jabbour et al. (2011) identified and validated the following SCM constructs: SC integration, information sharing, customer and supplier relationships, and postponement. Sezen (2008) investigated SCM in terms of the following aspects: SC integration, SC information sharing, and SC design. He found that none of the three SCM practices affected flexibility performance, and only SC design affected output performance and resource performance. Sundram et al. (2011) measured SCM using the following constructs: supplier and customer relationships, level and quality of information sharing, postponement, agreed goals and vision, and reward/risk sharing. They found that all SCM practices, except customer relationship, positively affected SC performance. Ibrahim and Ogunyemi (2012) investigated SCM in terms of supplier and customer partnerships, and level and quality of information sharing. They found that SCM practices were positively related to both SC performance and export performance. Lee et al. (2007) measured SCM using the following practices: customer linkage, supplier linkage, and internal linkage. They found that internal integration is the most contributing practice to cost performance while integration with the supplier is the most important practice to SC reliable performance. Flynn et al. (2010) investigated the impact of SC integration on operational and business performance. They found that internal integration and customer integration were positively related to operational performance, while only internal integration was related to business performance. They also found that supplier integration was neither related to operational nor to business performance.

Based on our literature review, we defined five SCM practices as the most frequently used practices in the SC literature: supplier integration, internal integration, customer integration, information sharing, and postponement. These practices will be used in our study. We discuss these practices in the following sub-sections.

\subsubsection{Supplier Integration}

Supplier integration is defined as "The long-term relationship between the organization and its suppliers. It is designed to leverage the strategic and operational capabilities of individual participating organizations to help 
them achieve significant ongoing benefits" (Li et al., 2004).

Supplier integration characterized by various aspects and activities such as information sharing, coordination, trust, shared technology, integrated processes, long-term contracts, assisting suppliers to improve production processes, fostering quality improvements, investing in supplier's assets, including suppliers in new product development, improving supplier's overall capabilities, risk and reward sharing, and shared gains from development efforts (Dyer et al., 1998; Echtelt et al., 2008). As such, integration results in improved decision making, enhanced knowledge sharing, aligned capabilities, built learning routines, and increased performance of SC partners (Echtelt et al., 2008).

Trust enhances the degree of commitment between the two parties, reduces transactional costs, improves cooperation, enhances the satisfaction of the two parties, decreases the formal contracts, and reduces conflicts (Sahay, 2003).

\subsubsection{Internal Integration}

Internal integration is defined as "the degree to which a manufacturer structures its own organizational strategies, practices and processes into collaborative, synchronized processes, in order to fulfill its customers' requirements and efficiently interact with its suppliers" (Flynn et al., 2010). Internal integration is an essential practice that should be implemented prior to moving to achieve external integration (Vanichchinchai \& Igel, 2009). Internal integration deals with integrating and linking information among different organizational departments, creating an easy access to inventory information, developing an easy accessed integrated database that encompasses main operational data, integrating production processes using advanced information systems, and linking production and marketing departments using computerized planning systems (Lee et al., 2007).

\subsubsection{Customer Integration}

Customer integration is defined as "demand management practices through long-term customer relationship, satisfaction improvement, and complaint management" (Tan et al., 1998). The fundamental aspect of customer relationship is the focus on key customers to understand their needs and requirements and to satisfy them (Sheth et al., 2000).

Customer integration includes different activities and practices such as integrated problem-solving initiatives, direct customer contacts, managing customer complaints, increasing customer satisfaction, and establishing long-range relations with customers (Boulding et al., 2005; Sousa, 2003; Tan et al., 1998).

Customer integration is expected to yield different benefits to organizations. Such benefits include the ability to differentiate products from competitors, increased market share and retention of profitable customers, improved customer loyalty, quickly resolving potential problems, shared knowledge and expertise concerning new technologies, deep understanding of customer needs, and rapid responses to customers (Magretta, 1998; Wasti \& Jeffrey, 1999).

\subsubsection{Information Sharing}

Information sharing is defined as "The extent to which critical and proprietary information is communicated to one's supply chain partner" ( $\mathrm{Li}$ et al., 2004). The advancements of information technology have greatly contributed to the evolution of sharing information throughout the SC. Regular exchanges of information enables SC parties to perform as a single body (Stein \& Sweat, 1998). Shared information has different kinds related to inventory, resources, products, demands, delays, and planning information (Sakka \& Botta-Genoulaz, 2009). It may also include information about quality, logistics, customer and general market information, and design information (Singh, 2013). In order to yield best results, shared information has to be adequate, accurate, credible, and timely ( $\mathrm{Li}$ et al., 2004). Information sharing affects performance in terms of improved customer responsiveness, decreased costs, enhanced service levels, and reduced levels of complexity (Zhao et al., 2002).

\subsubsection{Postponement}

Postponement is defined as "the practice of moving forward as far as possible one or more operations or activities to a later point in the supply chain" (Van Hoek et al., 1999). Postponement will be the appropriate SC strategy in the following situations: costly and expensive products, short product life cycles, long delivery time, high demand variance, high degree of customization, innovative products, high variety of products with low volume, and low delivery shipments (Pagh \& Cooper, 1998; Van Hoek, 2001).

Postponement brings several benefits to companies. It enables companies to control the risks related to product diversity and uncertain demand, increases flexibility, enables companies to keep their options open before the availability of sufficient information, reduces SC costs by keeping undifferentiated inventories, reduces levels of 
inventory, improves forecasting effectiveness, facilitates mass customization, and reduces production cycle times (Yang et al., 2005; Li et al., 2004).

\subsection{Supply Chain Performance}

There is no consensus among researchers concerning the best measures of SC performance (Ibrahim \& Ogunyemi, 2012; Flynn et al., 2010). Jeong and Hong (2007) measured SC performance in terms of delivery reliability, responsiveness, flexibility, cost, and efficiency. Sezen (2008) used flexibility, output, and resource performance to measure SC performance. Lee et al. (2007) measured SC performance using cost-containment and reliability measures. Vanichchinchai and Igel (2009) used the variables of cost, flexibility, relationship, and responsiveness to measure SC performance. Ibrahim and Ogunyemi (2012) measured SC performance using SC flexibility and SC efficiency. Some authors used one construct to measure SC performance (i.e., Sundram et al., 2011; Gunasekaran et al., 2004; Elmuti, 2002). Efficiency and effectiveness aspects have been widely used in the literature to measure SC performance (Lee et al., 2007; Ibrahim \& Ogunyemi, 2012; Tan et al., 1998; Li et al., 2006). Gunasekaran et al. (2004) argued that flexibility is the most important and critical variable to measure SC effectiveness.

We used in this study the measures of efficiency and effectiveness to measure SC performance. Efficiency means the usage of minimum inputs while effectiveness is related to meeting customer's unique needs and demand variability (Fawcett \& Clinton, 1996). Efficiency is usually reflected by using cost and inventory turnover measures (Gunasekaran et al., 2004; Lee et al., 2007). Effectiveness is reflected by using flexibility performance, delivery performance, customer responsiveness, and time to market ( $\mathrm{Li}$ et al., 2004; Lee et al., 2007; Ibrahim \& Ogunyemi, 2012).

\section{Framework and Research Hypotheses}

\subsection{Research Framework}

The proposed framework for this research is illustrated in Figure 1. The framework shows the impact of SCM practices on SC performance in terms of SC efficiency and SC effectiveness. To reflect more accurate analysis between SCM practices and SC performance, the function of competitive intensity is moderated. The research hypotheses are discussed in this section.

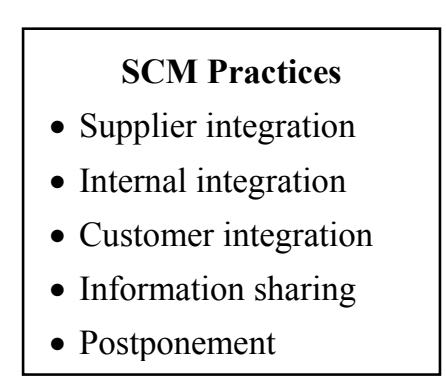

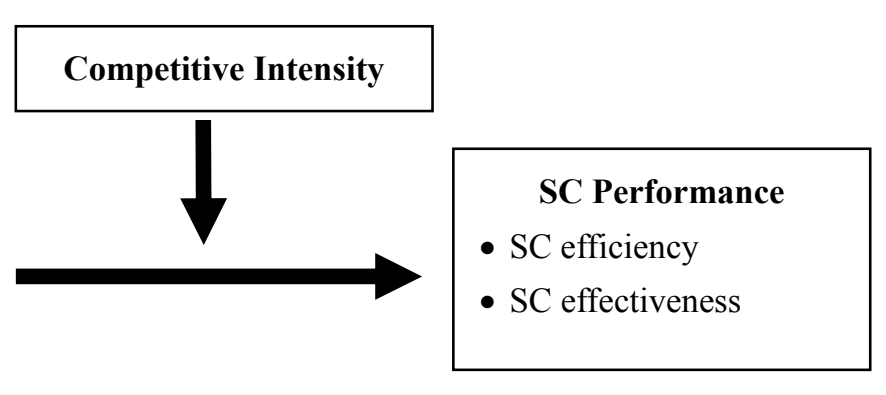

Figure 1. Research framework

\subsection{Research Hypotheses}

\subsubsection{The Impact of SCM Practices on SC Performance}

Supplier integration implies that companies will tend to work with fewer suppliers. As such, cost of supplied materials will be reduced due to economies of scale for suppliers (Zhao et al., 2013). Supplier integration also minimizes the inspections of incoming materials as the customer firm will have an impetus to assist and certify suppliers on quality management resulting in improved productivity and quality and better design of parts (De Toni \& Nassimbeni, 2000). Moreover, supplier integration will ensure a flexible and reliable supply of materials in a mass customization environment at a low cost (Liu et al., 2010). Furthermore, integrating suppliers in new product development activities result in improved product quality, reduced development time and engineering changes, reduced costs, and early resolved potential problems of the supplier (De Toni \& Nassimbeni, 2000). Generally, supplier integration positively affects lead time performance, manufacturing performance (Vachon \& Klassen, 2008), delivery performance, customer service, and competitive advantage (Gimenz \& Ventura, 2005). H1a: Supplier integration is positively related to SC efficiency. 
H2a: Supplier integration is positively related to SC effectiveness.

Internal integration allows companies to meet and improve production scheduling through cross-functional integration, supply and demand planning, production scheduling and planning, and customer demand management (Stratman \& Roth, 2002). Internal integration minimizes conflicts and misinterpretations, facilitates the flow of information among different functions, and focuses all the efforts towards fulfilling customer orders and requirements in a timely manner. Well integrated functions result in reduced inventories, enhanced delivery speed, and increased customer responsiveness (Zhao et al., 2013). Gimenez and Ventura (2003) found empirically that internal integration had a positive influence on performance.

$\mathrm{H} 1 \mathrm{~b}$ : Internal integration is positively related to SC efficiency.

$\mathrm{H} 2 \mathrm{~b}$ : Internal integration is positively related to SC effectiveness.

Customer integration allows companies to enhance customer responsiveness due to increased ability to anticipate and track customer complaints, demands, and needs (Hausman \& Stock, 2003). Kratochvil and Carson (2005) argued that customer integration leads to reduced steps in a business process and minimized losses by eliminating misunderstanding in the order process, which subsequently result in lower costs, improved quality and delivery, and increased customer responsiveness. Companies are forced to indentify customer needs and wants in a timely manner in order to be able to respond to their varying preferences. Integrating customers allows companies to identify their needs and address them through SC tasks such as continuous replenishment, flexibility and stock management, and on time delivery (Cox et al., 2003). Customer integration enables companies to differentiate their products from rivals and considerably enhance the provided value to customers and increase customer satisfaction and loyalty (Cox, 2004).

H1c: Customer integration is positively related to SC efficiency.

$\mathrm{H} 2 \mathrm{c}$ : Customer integration is positively related to SC effectiveness.

Moberg et al. (2002) asserted that timely and shared information in the SC results in more accurate decisions and can be regarded as a pillar of superior performance. Shared information enables companies to enhance inventory control and management and increase inventory turnover. Furthermore, shared information among SC partners improves delivery performance, logistics communication, and SC planning (Trevile et al., 2004). Additionally, information sharing significantly reduces costs (Wang et al., 2006), shortens cycle time (Lin et al., 2002), and improves overall SC performance (Zhao et al., 2002).

H1d: Information sharing is positively related to SC efficiency.

H2d: Information sharing is positively related to SC effectiveness.

Postponement enables companies to reduce inventory costs by avoiding holding large inventories. Additionally, the quality of supplied materials is expected to be enhanced as frequent deliveries in small lots make it possible to detect any quality problems at a very early stage. Postponement is also expected to increase flexibility levels by enhancing the company's ability to change the mix of products in a smooth and reliable manner. As a subsequence, delivery performance of a firm is expected to be enhanced and improved. Postponement allows companies to deal with demand uncertainties, demand variance, and short product life cycle in a dynamic and changing environment (Huang \& Li, 2009). Furthermore, postponement increases company's ability to deliver more customized products through flexibility (Van Hoek, 2001). As such, companies become more responsive towards customer demand and eventually SC performance is expected to be enhanced.

H1e: Postponement is positively related to SC efficiency.

$\mathrm{H} 2 \mathrm{e}$ : Postponement is positively related to $\mathrm{SC}$ effectiveness.

3.2.2 The Moderating Effects of Competitive Intensity.

Competitive intensity refers to the extent of competition in an industry (Kohli \& Jaworski, 1990). Competition is usually intensive due to extensive promotional and advertising campaigns, introducing new and innovative competitive ways by companies, and price wars (Slater \& Narver, 1994). Jaworski and Kohli (1993) indicated that when competition is low, companies can perform well, without being market-oriented since customers do not have sufficient alternative options. They further indicated that when competition is high, customers have several alternatives to please their requirements, and a company that is not market-oriented may lose its customers to competitors. Fynes et al. (2005) asserted that in a competitive situation where differentiation strategy is applied, high levels of SC linkages are essential to improve performance, while such strong linkages may not be required in low competitive environments with less differentiation. Generally, the moderating effect of competitive intensity is still unclear. On one hand, it may have a positive impact as it provides companies with 
creativeness and opportunities (Jermias, 2006). While on the other hand, it may reduce the positive impact of innovative practices on performance due to the associated risk of failure (García-Zamora et al., 2013).

H3a: The relationship between supplier integration and SC efficiency is moderated by competitive intensity.

$\mathrm{H} 3 \mathrm{~b}$ : The relationship between internal integration and $\mathrm{SC}$ efficiency is moderated by competitive intensity.

$\mathrm{H} 3 \mathrm{c}$ : The relationship between customer integration and $\mathrm{SC}$ efficiency is moderated by competitive intensity.

$\mathrm{H} 3 \mathrm{~d}$ : The relationship between information sharing and SC efficiency is moderated by competitive intensity.

$\mathrm{H} 3 \mathrm{e}$ : The relationship between postponement and $\mathrm{SC}$ efficiency is moderated by competitive intensity.

H4a: The relationship between supplier integration and $\mathrm{SC}$ effectiveness is moderated by competitive intensity.

$\mathrm{H} 4 \mathrm{~b}$ : The relationship between internal integration and SC effectiveness is moderated by competitive intensity.

$\mathrm{H} 4 \mathrm{c}$ : The relationship between customer integration and $\mathrm{SC}$ effectiveness is moderated by competitive intensity.

$\mathrm{H} 4 \mathrm{~d}$ : The relationship between information sharing and $\mathrm{SC}$ effectiveness is moderated by competitive intensity.

H4e: The relationship between postponement and SC effectiveness is moderated by competitive intensity.

\section{Methodology}

\subsection{Data Collection}

A survey questionnaire was used to collect data for this study. To ensure content validity, the measurement scales were developed after conducting a thorough review of the related SCM literature. The survey was pilot tested by two professors that taught SCM courses, and pre-tested at two manufacturing companies, and was revised as needed.

The research population represented all manufacturing plants in Jordan. To attain a good representation level, one hundred and eighty manufacturing plants were visited personally by the authors. This is the common method of collecting data in Jordan as companies tend to ignore questionnaires sent by mail or e-mail. The companies were selected from different industries which included textile/garments, machinery, pharmaceutical, food, electrical, and chemical. Our initial objective was to administer the survey to SC managers; however, our visits revealed that some manufacturing companies did not have such a position. As such, we selected the manager whose responsibilities were most closely related to SC manager's duties, and requested him to fill out the questionnaire. Those managers included production managers, plant managers, and general managers. Some managers filled out the questionnaires in our presence, but the majority asked us to come back after some days to receive the filled out questionnaires. We collected one hundred and eleven answered questionnaires. Seven questionnaires were identified as unusable; four of them due to large amounts of missing data, and the other three due to selecting the same answer for all question items, and were excluded from further analysis. One hundred and four final usable questionnaires were used in the subsequent analysis representing a response rate of $57.7 \%$. Table 1 below shows frequencies and percentages of responding manufacturing companies classified by industry type.

Table 1. Manufacturing companies classified by industry type

\begin{tabular}{ccc}
\hline Manufacturing type & Frequency & Percent \\
\hline Electrical/electronic & 14 & $13.46 \%$ \\
Textile/ garments & 21 & $20.20 \%$ \\
food & 17 & $16.34 \%$ \\
Machinery/industrial & 29 & $27.89 \%$ \\
chemical & 16 & $15.38 \%$ \\
pharmaceutical & 7 & $6.73 \%$ \\
Total & 104 & $100 \%$ \\
\hline
\end{tabular}




\subsection{Measurement Analysis}

To ensure high validity and reliability of our measurement scales, the survey was adapted from some frequently cited previous studies (Lee et al., 2007; Ibrahim \& Ogunyemi, 2012; Rajaguru \& Matanda, 2009, Li et al., 2004; Flynn et al., 2010; Vanichchinchai \& Igel, 2009). One multi-item scale was used to measure each variable of our independent and dependent variables. Respondents were asked to answer the question items using a seven-point Likert scale where 1 pointed to strong disagreement and 7 pointed to strong agreement. To assess the reliability of our measurement scales, factor analysis was used with principal component's analysis to extract factors to ensure that all questions within a scale loaded onto one factor with eigenvalue greater than 1. Questions that had a factor loading less than 0.40 were excluded from further analysis.

Cronbach's $\alpha$-coefficient was applied to evaluate the reliability of the measurement scales. All 8 scales used in our study met the suggested standard of $\alpha \geq 0.70$ indicating that they all were internally consistent (Nunnally, 1978).

Table 2 below shows the mean values, standard deviations, and cronbach's $\alpha$-coefficients for the study constructs.

Table 2. Means, standard deviations, and cronbach's $\alpha$-coefficient

\begin{tabular}{lccc}
\hline Variable & Mean & Standard deviation & Cronbach's $\alpha$-coefficient \\
\hline 1. Supplier integration & 5.371 & 0.457 & 0.798 \\
2. Internal integration & 5.020 & 0.771 & 0.910 \\
3. Customer integration & 5.261 & 0.471 & 0.757 \\
4. Information sharing & 4.922 & 0.564 & 0.786 \\
5. Postponement & 4.573 & 0.491 & 0.711 \\
6. Competitive intensity & 5.405 & 0.658 & 0.785 \\
7. SC Efficiency & 4.779 & 0.717 & 0.874 \\
8. SC effectiveness & 5.576 & 0.809 & 0.764 \\
\hline
\end{tabular}

\section{Results and Discussion}

We used hierarchical regression analysis to test our hypotheses. Two separate hierarchical regression models were used, with one SC performance dimension as a dependent variable in each one. In the first hierarchical regression model, SC efficiency was used as a dependent variable (Table 3). Three steps were used to test the related hypotheses. In the first step, SCM practices were entered so that to investigate their impact on SC efficiency, hypotheses H1a, H1b, H1c, H1d, and H1e. In the second step, the moderator variable, competitive intensity, was included. In the third step, the interactions between competitive intensity and each SCM practice were entered, hypotheses $\mathrm{H} 3 \mathrm{a}, \mathrm{H} 3 \mathrm{~b}, \mathrm{H} 3 \mathrm{c}, \mathrm{H} 3 \mathrm{~d}$, and $\mathrm{H} 3 \mathrm{e}$. Prior to performing the interaction terms, we mean-centered SCM practices, the independent variables, and competitive intensity, the moderator variable, to reduce potential muliticollinearity. In order to ensure that multicollinearity did not affect the results of the regression analysis, variance inflation factor (VIF) diagnostic method was performed. The values of VIF ranged less than 2.249 suggesting that multicollinearity did not influence the results of the regression model.

The results of the first step in the regression model showed that SCM practices as a block significantly contributed to the explanation of the variance in the level of SC efficiency $\left(\mathrm{R}^{2} \mathrm{adj}=0.280, \mathrm{P}<0.01\right)$. As for individual SCM practices, three practices, internal integration, information sharing, and postponement positively and significantly impacted SC efficiency. Supplier integration was negatively and significantly related to SC efficiency, and customer integration was insignificantly related to SC efficiency. Hypotheses H1b, H1d, and H1e were accepted while hypotheses H1a and H1c were rejected.

In the second step, the addition of competitive intensity into the regression model resulted in an additional significant change $(4.3 \%)$ of the variance in SC efficiency performance $(\mathrm{p}<0.01)$. In the third step, the addition of the interactions between competitive intensity and the five SCM practices resulted in a further significant change in $\mathrm{R}^{2}(13.3 \%, \mathrm{p}<0.01)$, implying that there was an additional increase in the predictive power of this model. The results of the third step showed that competitive intensity had a positive and significant $(\mathrm{p}<0.01)$ impact on the relationship between supplier integration and SC efficiency, therefore hypothesis $\mathrm{H} 3 \mathrm{a}$ was 
accepted. The moderating effect of competitive intensity on the relationship between internal integration and SC efficiency was found significant and positive $(\mathrm{p}<0.01)$, supporting hypothesis H3b. Also, the results showed a significant $(\mathrm{p}<0.05)$, but negative moderating effect of competitive intensity on the relationship between customer integration and SC efficiency, supporting H3c. Nonetheless, hypotheses H3d and H3e were not supported because the results showed no moderating effects of competitive intensity on the relationship between information sharing and SC efficiency as well as on the relationship between postponement and SC efficiency.

Our finding that supplier integration contributed significantly and negatively to SC efficiency might appear surprising. However, understanding the costs associated with such integration may potentially explain this result. Supplier integration includes several activities undertaken by the customer firm to develop supplier's capabilities and competencies. Such activities may include quality improvement efforts, process improvement and redesign, technology change, and other investments aiming at developing suppliers. The results suggested that such activities will have a negative effect on SC efficiency in stable markets that are not characterized by intensive competition. Our results were consistent with the findings of Swink et al. (2007) and Koufteros et al. (2005) who found that supplier involvement had a negative effect on some performance dimensions. Our results were inconsistent with the results of Lee et al. (2007) and Devaraj et al. (2007) who found that supplier integration positively affected some performance dimensions. The results of the interaction effect showed that in environments characterized by intensive competition, the impact of supplier integration on SC efficiency became significant and positive. This is an important finding implying that the higher levels of supplier integration when competitive intensity exists; the higher levels of SC efficiency are achieved. Investments in supplier development activities are justified in competitive environments, and are expected to improve SC efficiency performance of the customer firm.

Internal integration proved to be the most contributing SCM practice to SC efficiency. Also, the interaction effect of competitive intensity on the relationship between internal integration and SC efficiency was significant and positive. The findings implied that whether the markets are characterized by low competition or intensive competition, internal integration represents a crucial SCM tool to improve SC efficiency. Our results were consistent with the results of Flynn et al. (2010) and Saeed et al. (2005) who found that internal integration affected operational performance and process efficiency respectively.

The main effects of information sharing and postponement on SC efficiency proved to be positive and significant. No moderating effects were found of competitive intensity on the relationship between the two variables and SC efficiency.

Customer integration did not contribute significantly to SC efficiency. Furthermore, the moderating effect of competitive intensity on the relationship between customer integration and SC efficiency was significant and negative. That means the higher customer integration efforts undertaken when competitive intensity exists, the lower SC efficiency levels are yielded. Generally, our results were consistent with the results of Sundram et al. (2011) and Lee et al. (2007) who found that customer integration did not affect SC performance and cost performance respectively. The possible explanation is that customer integration efforts require additional investments and resources to enable a timely and reliable contact with customers. While such contacts might be necessary in competitive environments, their expected effect on SC efficiency is negative.

To test the rest of our hypotheses, we used the second hierarchical regression model with SC effectiveness performance as a dependent variable (Table 4). In a similar manner, three steps were used to test the related hypotheses. In the first step, SCM practices were entered as a block to examine their impact on SC effectiveness, hypotheses $\mathrm{H} 2 \mathrm{a}, \mathrm{H} 2 \mathrm{~b}, \mathrm{H} 2 \mathrm{c}, \mathrm{H} 2 \mathrm{~d}$, and $\mathrm{H} 2 \mathrm{e}$. In the second step, the moderator variable, competitive intensity, was added. In the third step, the interactions between competitive intensity and each SCM practice were entered, hypotheses $\mathrm{H} 4 \mathrm{a}, \mathrm{H} 4 \mathrm{~b}, \mathrm{H} 4 \mathrm{c}, \mathrm{H} 4 \mathrm{~d}$, and $\mathrm{H} 4 \mathrm{e}$. The values of VIF ranged less than 2.634 suggesting that multicollinearity was not a problem in the second regression model.

The results of the first step in the regression model showed that SCM practices as a block significantly contributed to the explanation of the variance in the level of SC effectiveness $\left(\mathrm{R}^{2} \mathrm{adj}=0.211, \mathrm{P}<0.01\right)$. As for individual SCM practices, three practices, internal integration, customer integration, and postponement, positively and significantly affected SC effectiveness performance. Supplier integration and information sharing were insignificantly related to SC effectiveness. Hypotheses $\mathrm{H} 1 \mathrm{~b}, \mathrm{H} 1 \mathrm{c}$, and H1e were accepted while hypotheses H1a and H1d were rejected. 
Table 3. Hierarchical regression analysis of efficiency

\begin{tabular}{|c|c|c|c|}
\hline Variables & Step 1 & Step 2 & Step 3 \\
\hline (Constant) & 1.029 & -0.259 & -1.146 \\
\hline \multicolumn{4}{|l|}{ Independent variables } \\
\hline Supplier integration & $-0.397 * * *$ & $-0.471 * * *$ & $-0.337 * * *$ \\
\hline Internal integration & $0.289 * * *$ & $0.309 * * *$ & 0.151 \\
\hline Customer integration & 0.118 & $0.159^{*}$ & $0.161^{*}$ \\
\hline Information sharing & $0.276^{* *}$ & $0.257^{* *}$ & $0.231^{*}$ \\
\hline Postponement & $0.267 * * *$ & $0.318^{* * *}$ & $0.355^{* * *}$ \\
\hline \multicolumn{4}{|l|}{ Moderating variable } \\
\hline Competitive intensity (CI) & & $0.222 * * *$ & $0.282 * * *$ \\
\hline \multicolumn{4}{|l|}{ Interaction effects } \\
\hline CI X Supplier integration & & & $0.293 * * *$ \\
\hline CI X Internal integration & & & $0.321 * * *$ \\
\hline CI X Customer integration & & & $-0.168 * *$ \\
\hline CI X Information sharing & & & -0.065 \\
\hline CI X Postponement & & & -0.112 \\
\hline $\mathrm{R}^{2}$ & 0.310 & 0.353 & 0.486 \\
\hline Adj. $R^{2}$ & 0.280 & 0.319 & 0.435 \\
\hline $\mathrm{F}$ & $10.406^{* * *}$ & $10.443 * * *$ & $9.462 * * *$ \\
\hline $\mathrm{R}^{2}$ change & & 0.043 & 0.133 \\
\hline F change & $10.406^{* * *}$ & $7.644 * * *$ & $5.716^{* * *}$ \\
\hline
\end{tabular}

$* \leq 0.10 ; * * \mathrm{P} \leq 0.05 ; * * * \mathrm{P} \leq 0.01$.

In the second step, the addition of competitive intensity into the model resulted in an additional significant change $(2.8 \%)$ of the variance in SC effectiveness $(\mathrm{p}<0.05)$. In the third step, the addition of the interactions between competitive intensity and the five SCM practices resulted in an additional significant change in $\mathrm{R}^{2}$ $(11.1 \%, \mathrm{p}<0.01)$, indicating that there was a further increase in the predictive power of this regression model. The results of the third step showed that competitive intensity had a significant and positive $(p<0.05)$ effect on the relationship between customer integration and SC effectiveness performance, supporting hypothesis H4c. The results also showed that competitive intensity had a significant and positive $(\mathrm{p}<0.05)$ impact on the relationship between information sharing and SC effectiveness, supporting hypothesis $\mathrm{H} 4 \mathrm{~d}$. The other three hypotheses, $\mathrm{H} 4 \mathrm{a}, \mathrm{H} 4 \mathrm{~b}$, and $\mathrm{H} 4 \mathrm{e}$, were rejected as the moderating effect was not found of competitive intensity on the relationship between each of those practices and SC effectiveness.

The results indicated that supplier integration did not contribute to SC effectiveness. Our results were consistent with the results of Flynn et al. (2010) and Stank et al. (2001) who found that supplier integration did not contribute to operational performance. This result can be viewed and justified by different ways. First, supplier integration may have an indirect effect on SC performance. Further studies are needed to investigate the direct and indirect effects of SCM practices on SC performance. Second, based on the context of Jordanian manufacturing companies that rely heavily on foreign suppliers, supplier integration might be viewed by several companies as unnecessary SCM practice. Third, Jordanian manufacturing companies may have implemented supplier integration having a strategic incentive to improve other dimensions of SC performance as well as operational and business performance. Further studies are also needed to address this issue. Additionally, no moderating effect was found of competitive intensity on the relationship between supplier integration and SC effectiveness.

Internal integration demonstrated to be the most important SCM practice that influenced SC effectiveness. It was also the most contributing practice that affected SC efficiency. Our results consistent with other studies that pointed to the key role of internal integration for superior SC performance (e.g., Germain \& Iyer, 2006; Droge et 
al., 2004). The moderating effect of competitive intensity was insignificant and did not affect the relationship between internal integration and SC effectiveness.

Customer integration was significantly and positively related to SC effectiveness. Furthermore, the moderating effect of competitive intensity on the relationship between customer integration and SC effectiveness was significant and positive. SC effectiveness included aspects such as flexibility, delivery, time to market, and ability to deal with customer's queries. Manufacturing companies may not be able to achieve high levels of SC effectiveness without properly integrating customers. This even would be of critical importance in highly competitive environments. Our results were consistent with the results of Flynn et al. (2010) and Lee et al. (2007) who found that customer integration affected operational performance and reliability performance respectively.

The main effect of information sharing on SC effectiveness was positive, but insignificant. However, the moderating effect of competitive intensity on the relationship between information sharing and SC effectiveness was positive and significant. This is an important finding that highlighted the role of information sharing in competitive environments. When low or moderate competition exists, the results suggested that information sharing did not affect effectiveness of SC. Nonetheless, in highly competitive markets the higher the levels of shared information, the higher the levels of SC effectiveness. Our results were inconsistent with the results of Sezen (2008) who found that information sharing did not affect flexibility, output, and resource performance dimensions. However, our results were consistent with the results of Zhao et al. (2002) and Moberg et al. (2002) who found that information sharing affected SC performance.

Postponement proved to be positively and significantly related to SC effectiveness. The moderating effect of competitive intensity on the relationship between postponement and SC effectiveness was negative, but insignificant. Our results were consistent with the results of Li et al. (2004) and Sundram et al. (2011) who found that postponement affected competitive advantage and SC performance respectively.

Table 4. Hierarchical regression analysis of effectiveness

\begin{tabular}{|c|c|c|c|}
\hline Variables & Step 1 & Step 2 & Step 3 \\
\hline (Constant) & -0.402 & -1.570 & -0.215 \\
\hline \multicolumn{4}{|l|}{ Independent variables } \\
\hline Supplier integration & -0.144 & $-0.204 *$ & $-0.213 *$ \\
\hline Internal integration & $0.220 * *$ & $0.236^{* *}$ & 0.168 \\
\hline Customer integration & $0.201 * *$ & $.234 * *$ & $0.167 *$ \\
\hline Information sharing & 0.174 & 0.158 & .162 \\
\hline Postponement & $0.215^{* *}$ & $0.256^{* * *}$ & 0.151 \\
\hline \multicolumn{4}{|l|}{ Moderating variable } \\
\hline Competitive intensity (CI) & & $0.178^{* *}$ & $* * 0.241$ \\
\hline \multicolumn{4}{|l|}{ Interaction effects } \\
\hline CI X Supplier integration & & & -0.050 \\
\hline CI X Internal integration & & & 0.083 \\
\hline CI X Customer integration & & & $* * 0.218$ \\
\hline CI X Information sharing & & & $0.237^{* *}$ \\
\hline CI X Postponement & & & $-0.213^{*}$ \\
\hline $\mathrm{R}^{2}$ & 0.244 & .272 & 0.383 \\
\hline Adj. $R^{2}$ & 0.211 & .234 & 0.321 \\
\hline $\mathrm{F}$ & & $7.147 * * *$ & $6.200 * * *$ \\
\hline $\mathrm{R}^{2}$ change & & 0.028 & 0.111 \\
\hline F change & $7.485 * * *$ & $4.370^{* *}$ & $3.960 * * *$ \\
\hline
\end{tabular}

$* \leq 0.10 ; * * \mathrm{P} \leq 0.05 ; * * * \mathrm{P} \leq 0.01$ 


\section{Conclusions}

This study sought to investigate the effects of SCM practices on SC efficiency and SC effectiveness with the moderating effect of competitive intensity for a sample consisting of one hundred and four manufacturing companies in Jordan. Based on our study, the subsequent conclusions were derived.

First, the results concerning the impact of SCM practices as a block on SC efficiency and effectiveness are in line with previous research. Our study confirmed that SCM practices implemented by manufacturing companies are good indicators of SC efficiency and effectiveness. Manufacturing companies are recommended to implement SCM practices to enhance their performance.

Second, the study contributed to the existing research concerning SCM by investigating the impact of individual SCM practices on SC efficiency. Our results revealed that internal integration, information sharing, and postponement are the most important SCM practices respectively that affect SC efficiency.

Third, the results of our study indicated that while the impact of supplier integration on SC efficiency was significant and negative, it became significant and positive under high levels of competitive intensity. The existing studies provide contradicting and dissimilar results concerning the impact of supplier integration on performance. Our study extends the SCM literature by indicating the importance of supplier integration as a good indicator of SC efficiency in high competitive environments. The results also showed that the impact of internal integration on SC efficiency became more significant under high levels of competitive intensity.

Fourth, our study contributed to SCM literature by investigating the impact of individual SCM practices on SC effectiveness. The results showed that internal integration, postponement, and customer integration are the most contributing SCM practices to SC effectiveness. The study addressed another contradicting question in the literature concerning the impact of customer integration on SC performance. While customer integration did not affect SC efficiency, it is of vital importance to reap high levels of SC effectiveness.

Fifth, our results indicated that impacts of both customer integration and information sharing on SC effectiveness became more significant under high levels of competitive intensity. Manufacturing companies are recommended to increase the levels of implementation of these two practices in highly competitive environments in order to achieve superior levels of SC effectiveness.

The limitation of our study is that the data was collected from a single informant in each manufacturing plant. In some cases, informants were only partially responsible for some SCM activities. Further studies are needed with multiple informants so that to allow respondents to address their precise area of expertise resulting in a greater validity of the findings. Our sample size represents another limitation as we could not investigate the indirect effects of our variables. Additionally, we avoided using control variables such as firm size, firm age, and industry type in order to reduce potential multicollinearity which is expected to affect the results by increasing the number of variables in a regression model. Further studies are needed with larger sample size so that to investigate indirect effects of the variables and to include control variables. Finally, we included only one moderating effect in our framework. Other contextual factors may affect the relationship between SCM aspects and SC performance. Further studies are needed to investigate the moderating effects of other variables such as demand uncertainty, strategic goals, and innovation on the relationship between SCM practices and SC performance.

\section{References}

Boulding, W., Staelin, R., Ehret, M., \& Johnston, W. (2005). A CRM Roadmap: What We Know, Potential Pitfalls, and Where to Go. Journal of Marketing, 69(4), 155-167. http://dx.doi.org/10.1509/jmkg.2005.69.4.155

Christopher, M. (1998). Logistics and Supply Chain Management (2nd ed.). Englewood Cliffs, NJ: Prentice-Hall.

Cook, L., \& Heiser, D. (2011). The moderating effect of supply chain role on the relationship between supply chain practices and performance: An empirical analysis. International Journal of Physical Distribution \& Logistics Management, 41(2), 104-134. http://dx.doi.org/10.1108/09600031111118521

Cox, A. (2004). The art of the possible: relationship management in power regimes and supply Chains. Supply Chain Management: An International Journal, 9(5), 346-356. http://dx.doi.org/10.1108/13598540410560739

Cox, H., Mowatt, S., \& Prevezer, M. (2003). New product development and product supply within a network setting: the chilled ready-meal industry in the UK. Industry and Innovation, 10(2), 197-217. 
http://dx.doi.org/10.1080/1366271032000096644

De Toni, A., \& Nassimbeni, G. (2000). Just-in-time purchasing: an empirical study of operational practices, supplier development and performance. Omega, 28(6), 631-651. http://dx.doi.org/10.1016/S0305-0483(00)00016-5

Devaraj, S., Krajewski, L., \& Wei, J. C. (2007). Impact of e-business technologies on operational performance: the role of production information in the supply chain. Journal of Operations Management, 25(6), 1199-1216. http://dx.doi.org/10.1016/j.jom.2007.01.002

Droge, C., Jayaram, J., \& Vickery, S. K. (2004). The effects of internal versus external integration practices on time-based performance and overall firm performance. Journal of Operations Management, 22(6), 557-573. http://dx.doi.org/10.1016/j.jom.2004.08.001

Dyer, J. H., Cho, D. S., \& Chu, W. (1998). Strategic supplier segmentation: the next "best practice" in supply chain management. California Management Review, 40(2), 57-77. http://dx.doi.org/10.2307/41165933

Echtelt, F., Wynstra, F., Weele, A., \& Duysters, G. (2008). Managing Supplier Involvement in New Product Development: A Multiple-Case Study. The Journal of Product Innovation Management, 25(2), 180-201. http://dx.doi.org/10.1111/j.1540-5885.2008.00293.x

Elmuti, D. (2002). The Perceived Impact of Supply Chain Management on Organizational Effectiveness. The Journal of Supply Chain Management, 38(2), 49-57. http://dx.doi.org/10.1111/j.1745-493X.2002.tb00135.x

Fawcett, S. E., \& Clinton, S. R. (1996). Enhancing logistics performance to improve the competitiveness of manufacturing organization. Production and Inventory Management, 37(1), 40-46.

Flynn, B. B., Huo, B., \& Zhao, X. (2010). The impact of supply chain integration on performance: A contingency and configuration approach. Journal of Operations Management, 28(1), 58-71. http://dx.doi.org/10.1016/j.jom.2009.06.001

Fynes, B., De Burca, S., \& Voss, C. (2005). Supply chain relationship quality: the competitive environment and performance. International Journal of Production Research, 43(16), 3303-3320. http://dx.doi.org/10.1080/00207540500095894

García-Zamora, E., González-Benito, O., \& Muñoz-Gallego, P. (2013). Organizational and environmental factors as moderators of the relationship between multidimensional innovation and performance. Innovation: Management, Policy \& Practice, 15(2), 224-244. http://dx.doi.org/10.5172/impp.2013.15.2.224.

Gensheng, L., Shah, R., \& Schroeder, R. (2010). Managing demand and supply uncertainties to achieve mass customization ability. Journal of Manufacturing Technology Management, 21(8), 990-1012. http://dx.doi.org/10.1108/17410381011086801

Germain, R., \& Iyer, K. N. S. (2006). The interaction of internal and downstream integration and its association with performance. Journal of Business Logistics, 27(2), 29-53. http://dx.doi.org/10.1002/j.2158-1592.2006.tb00216.x

Gimenez, C., \& Ventura, E. (2005). Logistics-production, logistics-marketing and external integration: Their impact on performance. International Journal of Operations \& Production Management, 25(1), 20-38. http://dx.doi.org/10.1108/01443570510572222

Gimenez, C., \& Ventura, E. (2003). Supply Chain Management as a competitive advantage in the Spanish grocery sector. The International Journal of Logistics Management, 14(1), 77-88. http://dx.doi.org/10.1108/09574090310806558

Gunasekaran, A., Patel, C., \& McGaughey, R. E. (2004). A framework for supply chain performance measurement. Int. J. Production Economics, 87(3), 333-347. http://dx.doi.org/ 10.1016/j.ijpe.2003.08.003.

Hausman, A., \& Stock, J. R. (2003). Adoption and implementation of technological innovations within long-term relationships. Journal of Business Research, 56(8), 681-686. http://dx.doi.org/10.1016/S0148-2963(01)00313-7

Huang, Y., \& Li, S. (2009). The application situation and determinants of postponement: A field survey for large manufacturers in Greater China. Journal of Manufacturing Technology Management, 20(6), 787-803. http://dx.doi.org/10.1108/17410380910975078

Ibrahim, S. E., \& Ogunyemi, O. (2012). The effect of linkages and information sharing on supply chain and export performance: An empirical study of Egyptian textile manufacturers. Journal of Manufacturing 
Technology Management, 23(4), 441-463. http://dx.doi.org/10.1108/17410381211230394

Jabbour, A. B. L., Filho, A. G. A., Viana, A. B. N., \& Jabbour, C. J. C. (2011). Measuring supply chain management practices. Measuring Business Excellence, 15(2), 18-31. http://dx.doi.org/10.1108/13683041111131592.

Jaworski, B. J., \& Kohli, A. K. (1993). Market orientation: antecedents and consequences. Journal of Marketing, 57(3), 53-70. http://dx.doi.org/10.2307/1251854

Jeong, J. S., \& Hong, P. (2007). Customer orientation and performance outcomes in supply chain management. Journal of Enterprise Information Management, 20(5), 578-594. http://dx.doi.org/10.1108/17410390710823707

Jermias, J. (2006). Competitive intensity as a quasi-moderator of the relationship between innovative efforts and performance. International Journal of Business, 8(3), 281-299.

Kohli, A. K., \& Jaworski, B. J. (1990). Market orientation: The construct, research propositions, and managerial implications. Journal of Marketing, 54(2), 1-18. http://dx.doi.org/10.2307/1251866

Koufteros, X., Vonderembse, M., \& Jayaram, J. (2005). Internal and external integration for product development: the contingency effects of uncertainty, equivocality, and platform strategy. Decision Sciences, 36(1), 97-133. http://dx.doi.org/10.1111/j.1540-5915.2005.00067.x

Kratochvil, C., \& Carson, C. (2005). Growing Modular: Mass Customization of Complex products, Services and Software (1st ed.). Berlin: Springer.

Lee, C. W., Kwon, I. G., \& Severance, D. (2007). Relationship between supply chain performance and degree of linkage among supplier, internal integration, and customer. Supply Chain Management: An International Journal, 12(6), 444-452. http://dx.doi.org/10.1108/13598540710826371.

Li, S., Ragu-Nathan, B., Ragu-Nathan, T. S., \& Subba Rao, S. (2004). The impact of supply chain management practices on competitive advantage and organizational performance. Omega, 34(2), 107-124. http://dx.doi.org/10.1016/j.omega.2004.08.002

Lin, F., Huang, S., \& Lin, S. (2002). Effects of information sharing on supply chain performance in electronic commerce. IEEE Transactions on Engineering Management, 49(3), 258-268. http://dx.doi.org/10.1109/TEM.2002.803388

Magretta, J. (1998). The power of virtual integration: an interview with Dell computers' Michael Dell. Harvard Business Review, 76(2), 72-84.

Moberg, C. R., Cutler, B. D., Gross, A., \& Speh, T. W. (2002). Identifying antecedents of information exchange within supply chains. International Journal of Physical Distribution \& Logistics Management, 32(9), 755-770. http://dx.doi.org/10.1108/09600030210452431

Nunnally, J. (1978). Psychometric Theory (2nd ed.). NY: McGraw-Hill.

Pagh, J. D., \& Cooper, M. C. (1998). Supply chain postponement and speculation strategies: how to choose the right strategy. Journal of Logistics Management, 19(2), 13-33.

Saeed, K. A., Malhotra, M. K., \& Grover, V. (2005). Examining the impact of interorganizational systems on process efficiency and sourcing leverage in buyer-supplier dyads. Decision Sciences, 36(3), 365-396. http://dx.doi.org/10.1111/j.1540-5414.2005.00077.x

Sahay, B. S. (2003). Understanding trust in supply chain relationships. Industrial Management \& Data Systems, 103(8), 553-563. http://dx.doi.org/10.1108/02635570310497602

Sakka, O., \& Botta-Genoulaz, V. (2009). A model of Factors Influencing the Supply Chain Performance. Proceedings of CIE 2009, 913-918. http://dx.doi.org/10.1109/ICCIE.2009.5223796

Sezen, B. (2008). Relative effects of design, integration and information sharing on supply chain performance. Supply Chain Management: An International Journal, 13(3), 233-240. http://dx.doi.org/10.1108/13598540810871271

Sheth, J., Sisodia, R., \& Sharma, A. (2000). The Antecedents and Consequences of Customer-Centric Marketing. Journal of the Academy of Marketing Science, 28(1), 55-66. http://dx.doi.org/10.1177/0092070300281006

Singh, R. K. (2013). Prioritizing the factors for coordinated supply chain using analytic hierarchy process (AHP). Measuring Business Excellence, 17(1), 80-98. http://dx.doi.org/ 10.1108/13683041311311383 
Slater, S., \& Narver, J. (1994). Does competitive environment moderate the market orientation — performance relationship? Journal of Marketing, 58(1), 46-55. http://dx.doi.org/10.2307/1252250

Sousa, R. (2003). Linking quality management to manufacturing strategy: an empirical investigation of customer focus practices. Journal of Operations Management, 21(1), 1-18. http://dx.doi.org/10.1016/S0272-696302)00055-4

Stank, T. P., Keller, S. B., \& Closs, D. J. (2001). Performance benefits of supply chain integration. Transportation Journal, 41(2), 31-46.

Stein, T., \& Sweat, J. (1998). Killer supply chains. Information week, 708(9), 36-46.

Stock, J., \& Boyer, S. (2009). Developing a consensus definition of supply chain management: a qualitative study. International Journal of Physical Distribution \& Logistics Management, 39(8), 690-711. http://dx.doi.org/10.1108/09600030910996323

Stratman, J., \& Roth, A. V. (2002). Enterprise resource planning (ERP) competence constructs: two-stage multiitem scale development and validation. Decision Sciences, 33(4), 601-628. http://dx.doi.org/10.1111/j.1540-5915.2002.tb01658.x

Sundram, V. P., Ibrahim, A. R., \& Govindaraju, V. G. R. (2011). Supply chain management practices in the electronics industry in Malaysia: Consequences for supply chain performance. Benchmarking: An International Journal, 18(6), 834-855. http://dx.doi.org/10.1108/14635771111180725

Swink, M., Narasimhan, R., \& Wang, C. (2007). Managing beyond the factory walls: effects of four types of strategic integration on manufacturing plant performance. Journal of Operations Management, 25(1), 148-164. http://dx.doi.org/10.1016/j.jom.2006.02.006

Tan, K. C., Kannan, V. R., \& Handfield, R. B. (1998). Supply chain management: supplier performance and firm performance. International Journal of Purchasing and Materials Management, 34(3), 2-9.

Trevile, S. D., Shpiro, R. D., \& Hameri, A. (2004). From supply chain to demand chain: the role of lead time reduction in improving demand chain performance. Journal of Operations Management, 21(6), 613-627. http://dx.doi.org/10.1016/j.jom.2003.10.001

Vachon, S., \& Klassen, R. D. (2008). Environmental management and manufacturing performance: the role of collaboration in the supply chain. International Journal of Production Economics, 111(2), 299-315. http://dx.doi.org/10.1016/j.ijpe.2006.11.030

Van Hoek, R. I. (2001). The rediscovery of postponement: a literature review and directions for research. Journal of Operations Management, 19(2), 161-184. http://dx.doi.org/10.1016/S0272-6963(00)00057-7

Van Hoek, R. I., Vos, B., \& Commandeur, H. R. (1999). Restructuring European supply chains by implementing postponement strategies. Long Range Planning, 32(5), 505-518. http://dx.doi.org/10.1016/S0024-6301(99)00071-0

Vanichchinchai, A., \& Igel, B. (2009). Total quality management and supply chain management: Similarities and differences. The TQM Journal, 21(3), 249-260. http://dx.doi.org/10.1108/17542730910953022

Wang, E. T. G., Tai, J. C. F., \& Wei, H. L. (2006). A Virtual Integration Theory of Improved Supply-Chain Performance. Journal of Management Information Systems, 23(2), 41-64. http://dx.doi.org/10.2753/MIS0742-1222230203

Wasti, S., \& Jeffrey, L. (1999). Collaborating with Suppliers in Product Development: A U.S. and Japan Comparative Study. IEEE Transactions on Engineering Management, 46(2), 245-257. http://dx.doi.org/10.1109/17.797966

Williams, S. (2006). Managing and developing suppliers: can SCM be adopted by SMES? International Journal of Production Research, 44(18-19), 3831-3846. http://dx.doi.org/10.1080/00207540600849133

Wisner, J., \& Tan, K. (2000). Supply chain management and its impact on purchasing. Journal of Supply Chain Management, 36(4), 33-42. http://dx.doi.org/10.1111/j.1745-493X.2000.tb00084.x

Yang, B., Burns, B., \& Backhouse, C. (2005). An empirical investigation into the barriers to postponement. International Journal of Production Research, 43(5), 991-1005. http://dx.doi.org/10.1080/00207540412331316134

Zhao, X., Xie, J., \& Zhang, W. (2002). The impact of information sharing and order-coordination on supply chain performance. Supply Chain Management: An International Journal, 7(1), 24-40. 
http://dx.doi.org/10.1108/13598540210414364

Zhao, L., Huo, B., Sun, L., \& Zhao, X. (2013). The impact of supply chain risk on supply chain integration and company performance: a global investigation. Supply Chain Management: An International Journal, 18(2), 115-131. http://dx.doi.org/10.1108/13598541311318773

\section{Copyrights}

Copyright for this article is retained by the author(s), with first publication rights granted to the journal.

This is an open-access article distributed under the terms and conditions of the Creative Commons Attribution license (http://creativecommons.org/licenses/by/3.0/). 